sendo questionada por uma série de pesquisadores, principalmente na França onde a mistura social alcançou status de principal política urbana. ${ }^{3}$

No Brasil, o debate acadêmico sobre o tema é ainda marginal. Em um contexto no qual a segregação socioespacial é apontada como o efeito mais nefasto do processo de urbanização, questionar uma ideia-força como a da mistura social não é tarefa fácil, especialmente para aqueles intelectuais engajados com o ideário da reforma urbana e do direito à cidade. Como se opor à imagem utópica de uma cidade onde diferentes classes sociais habitam o mesmo endereço e compartilham o espaço público? A grandeza do discurso não faz calar, no entanto, algumas indagaçôes sobre a utilização da retórica da mistura social nos projetos de intervenção em áreas urbanas centrais brasileiras. Quais interesses encorajam a volta das classes médias para esses bairros? Estariam elas dispostas a conviver com os moradores de baixa renda, predominantes nas áreas centrais? É possível vislumbrarmos alguns efeitos nocivos desta "volta ao centro", tais como processos de gentrificação, expulsão branca e remoções? A importação de discursos e instrumentos urbanos supostamente bem-sucedidos deve ser avaliada com cautela, visto que a realidade brasileira apresenta características incompatíveis com a dos países centrais onde foram formulados - a inexistência de processos participativos e a inaplicabilidade de instrumentos garantidores do direito à moradia são algumas delas. Acompanhar o debate internacional alimenta reflexões e suscita provocações. Mas apenas a análise empírica e contextualizada pode nos oferecer respostas pertinentes.

3 Em 2010, a revista Espaces et Sociétés lançou um dossiê intitulado Paradoxes de la mixité sociale, cujos artigos tornaram-se uma relevante fonte de reflexões sobre o tema. Outra publicação importante é o livro Mixed communities: gentrification by stealth? organizado conjuntamente por Gary Bridge, Tim Butler e Loretta Lees, lançado em 2012 pela The Policy Press, University of Bristol.

\section{ARRAIAIS E VILAS D'EL REI: ESPAÇO E PODER NAS MINAS SETECENTISTAS}

Claudia Damasceno Fonseca

Belo Horizonte: Editora UFMG, 2011

Renato Cymbalista

Professor e pesquisador da Faculdade de Arquitetura e Urbanismo da Universidade de São Paulo

Defendido originalmente como tese de doutoramento na École des Hautes Études en Sciences Sociales, em Paris, o estudo Arraiais e Vilas d'El Rei: Espaço e Poder nas Minas Setecentistas vinha há algum tempo "comendo pelas bordas" o nosso debate sobre o território e a urbanização no período colonial. Finalmente publicado em língua portuguesa, torna-se um trabalho incontornável para quem estuda a rede urbana no período colonial. A autora faz uma devassa na documentação referente à ocupação do território e à rede urbana mineira desde o século XVII, abordando com originalidade e contundência todas as escalas do território, do intraurbano às relaçôes colônia-metrópole. O resultado é um livro muito extenso, cerca de 700 páginas nas quais - contrariamente às primeiras suspeitas - não há desperdício de espaço: a autora tem o que dizer em cada parágrafo.

O livro é dividido em três partes, cada uma delas com fôlego suficiente para ser, por si só, uma tese. A escolha foi construir olhares para o território com diferentes escalas, iniciando com uma lente mais distante e aproximando-se progressivamente do espaço urbano.

A primeira parte, Do sertão ao território, trata da conversão do território do sertão em território colonial, nas dimensōes políticas, administrativas e religiosas, mostrando como o território ocupava-se com as várias dimensões do poder colonial. Conforme era ocupado, o sertão se tornava distrito, concelho, freguesia, comarca. Tornava-se espaço das administrações civil e religiosa, controlando a vida dos moradores e sendo também instrumentalizadas por eles.

A segunda parte, As vilas e seus territórios, tem o foco ajustado para a escala das vilas: a interação e os contatos entre elas, a disputa entre elas por territórios de fronteira, a tensão com arraiais periféricos em luta 
pela autonomia administrativa, a estrutura de arrecadação de tributos associada ao domínio territorial, as contrapartidas de ordem espiritual que vinham amalgamadas com o controle do território.

E na terceira parte, Espaços e paisagens urbanas, o foco recai sobre o espaço intraurbano: a estrutura fundiária, o urbanismo, a dotação de infraestrutura e equipamentos pelas câmaras municipais.

O domínio de uma diversidade de fontes e de métodos de análise revela uma formação também múltipla: a graduação em Arquitetura e Urbanismo, o mestrado em Geografia e o doutorado em História. A apropriação do instrumental de cada disciplina permitiu à autora transitar com competência por fontes muito diversificadas, dos maços de população aos mapas históricos, à iconografia urbana de vilas e cidades, pesquisadas em arquivos dos dois lados do Atlântico. A autora soube recorrer aos relatos de memorialistas e se posicionar em relação à extensa bibliografia já existente tanto a referente aos estudos urbanos e territoriais quanto à história da América Portuguesa no sentido mais amplo. A cartografia da ocupação do território produzida pela autora é tão reveladora quanto o tratamento das fontes. Mostra as ondas de ocupação, a diferenciação da rede urbana entre vilas e arraiais mineradores e de abastecimento, as estratégias da população construindo alternativas à fugaz atividade mineradora $\mathrm{e}$ a relevância demográfica das atividades administrativas.

A leitura do livro de Claudia Damasceno nos força a repensar uma série de aspectos sobre nosso passado territorial.

A ideia de que nossos sertōes foram ocupados por caipiras desinformados à margem da sociedade é um deles. O livro mostra sertanejos com plena capacidade de agência, dominando claramente os códigos necessários para tornar a ida ao sertão uma conquista pessoal definitiva, com capacidade de diálogo e negociação com autoridades civis, autoridades religiosas e também com a Coroa de Portugal. Outra imagem a ser relativizada é a ideia de ocupação fluida do interior significar um vazio institucional, uma "terra-de ninguém". O livro mostra que as instituições portuguesas chegavam simultaneamente aos primeiros ocupantes dos arraiais. Mais uma imagem que o livro relativiza é a de um desconhecimento do território do interior por Portugal, causado pela distância e pelas baixas densidades populacionais. Ao contrário, a autora traz fontes escritas e cartográficas que revelam a Coroa com um notável conhecimento do território e de sua ocupação. Cada casa era reconhecida pela Coroa e disputada entre as vilas para fins de arrecadação de tributos.

As vilas e o território mineiro desvelados por Claudia Damasceno não existem de forma independente da agência dos diversos atores sociais, mas são mostradas de forma bem mais complexa, a materialidade do espaço se constrói a partir disso, revelando-se ao mesmo tempo como artefato que informa outras tantas agências.

Trata-se de história urbana e territorial em seu mais alto nível, que reconhece as grandes explicações da Colônia, mas não fica a reboque de nenhuma delas. A autora mostra simultaneamente a sociedade da América Portuguesa em toda a sua complexidade local, e também nas suas inúmeras relações com a Metrópole.

Arraiais e Vilas d'El Rei já nasce como referência obrigatória, e sua envergadura é algo raro em tempos como o nosso, de objetos cada vez mais recortados no tempo e no espaço. 